\title{
メカニカルアロイング法による $\mathrm{Mg}-\mathrm{Al}-\mathrm{Zn}$ 系焼結合金の作製と機械的性質
}

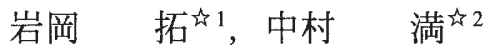 \\ 的岩手大学大学院, $\bar{T}$ 020-8551 盛岡市上田 4-3-5. \\ 的岩手大学工学部, $\overline{0} 020-8551$ 盛岡市上田 4-3-5.
}

\section{Preparation of Mg-Al-Zn Type Sintered Alloy by Mechanical Alloying Method and its Mechanical Properties}

\author{
Taku Iwaoka ${ }^{\text {is } 1}$ and Mitsuru Nakamura ${ }^{\text {th } 1}$ \\ ${ }_{41}$ Graduate Student, Iwate University, 4-3-5 Ueda, Morioka 020-8551, Japan. \\ ${ }^{\star 2}$ Fac. Eng., Iwate University, 4-3-5 Ueda, Morioka 020-8551, Japan.
}

Received February 6, 2008

\section{SYNOPSIS}

Mg-Al-Zn type mixed powder was mechanically alloyed (MA) by using a planetary ball mill under Ar atmosphere. The MA powders were sintered by vacuum hot pressing (HP). The change of constituent phase of HP materials was examined by XRD and FE-EPMA. Its mechanical properties were evaluated by Vickers hardness and compression tests. HP material was obtained by processing MA powder with mean particle size of $5.6 \mu \mathrm{m}$ at $673 \mathrm{~K}$ for $18 \mathrm{ks}$. Its hardness and $0.2 \%$ proof strength became HV164 and $546 \mathrm{MPa}$, respectively. It is considered that this HP material shows high mechanical properties due to the fine dispersion of particles of $\mathrm{Mg}_{17} \mathrm{Al}_{12}$ phase.

KEY WORDS

mechanical alloying, intermetallic compound, $\mathrm{Mg}-\mathrm{Al}-\mathrm{Zn}$ alloy, fine dispersion particle

\section{1 緒 言}

近年の地球環境問題から, 輸送機器の燃費改善のための軽 量化および各種機器のリサイクル可能率の向上が余儀なくさ れつつある. それらを達成するための素材の切り札として, 国内外においてマグネシウム合金が注目され，自動車部品や 家電製品の筐体への応用が急速に伸び，今後さらに拡大する と予測されている ${ }^{1}$ ，それに呼応するように，研究開発も活 発になり，例えば, ADC12に匹敵するクリープ特性を有する 耐熱マグネシウム合金の研究成果が報告されている2)。しか し, ダイカストなどの溶解鋳造法では, 溶融・凝固過程に起 因する流動性，耐熱間割れ性および而焼付き性などの鋳造性 が問題となっている。一方, 粉末冶金法の一種であるメカニ カルアロイング (以下 MA) 法は, 溶解を伴わず状態図に制約 されない自由な合金設計が可能であることから，新合金創製 の新しい技術として研究されている ${ }^{3}$. 特に, 高温でも安定 なセラミックスや金属間化合物を固相反応によって生成させ, $\mathrm{Mg}$ マトリックス中に微細分散させることにより高強度 $\mathrm{Mg}$ 合 金が得られることが報告されており ${ }^{4-7)}, \mathrm{Mg}$ 基材料にもこの 手法を適用できることが示されている.

本研究は, 最近注目されているマグネシウム合金がダイカ
ストなどの溶解鋳造法において耐熱間割れ性や耐焼付き性等 の問題があることから，MAによる粉末冶金法によってバル ク材の作製を試みたものである.

\section{2 試料および実験方法}

原料粉末は純 $\mathrm{Mg}$ 粉末 (平均粒子径 $80 \mu \mathrm{m}$ ), 純 $\mathrm{Al}$ 粉末 (平均 粒子径 $105 \mu \mathrm{m}$ ) および純 Zn 粉末(平均粒子径 $40 \mu \mathrm{m}$ ) を用いた. その SEM 像を Fig.1 に示す. 純 Mg 粉末は中央工産㮫製でフ レーク状, 純 $\mathrm{Al}$ 及び純 $\mathrm{Zn}$ 粉末は福田金属箔粉工業侏製で粒 状であった. Fig.2はMA法のプロセスおよびその条件を示す. まず, $\mathrm{Mg}: \mathrm{Al}: \mathrm{Zn}=90: 9: 1$ (AZ91 相当) に秤量した $\mathrm{Mg}-\mathrm{Al}-\mathrm{Zn}$ 系粗粉に, 潤滑剤としてステアリン酸㩊鈆 $\left(\mathrm{C}_{36} \mathrm{H}_{70} \mathrm{O}_{4} \mathrm{Zn}\right)$ を 0.8 〜 4.0 mass\%まで変化させて添加した.この粗粉を直径 $10 \mathrm{~mm}$ のステンレス鋼製ボールと共に Ar ガスで置換したグローブ ボックス(美和製作所, 1ADB-3型)中で, ステンレス鋼製粉 砕容器に封入した. ボールと粗粉の重量比は 16 とした.この 粉研容器を遊星型ボールミル(伊藤製作所, LP-4)に装着した。 回転数は $250 \mathrm{rpm}$ に固定し, ミリング時間は $18 \sim 108 \mathrm{ks}$ まで 変化させ，MA粉末を作製した，次に，このMA粉末を黒鈶 型に装填し, 真空焼結炉 (ネムス侏) を用いてホットプレス 


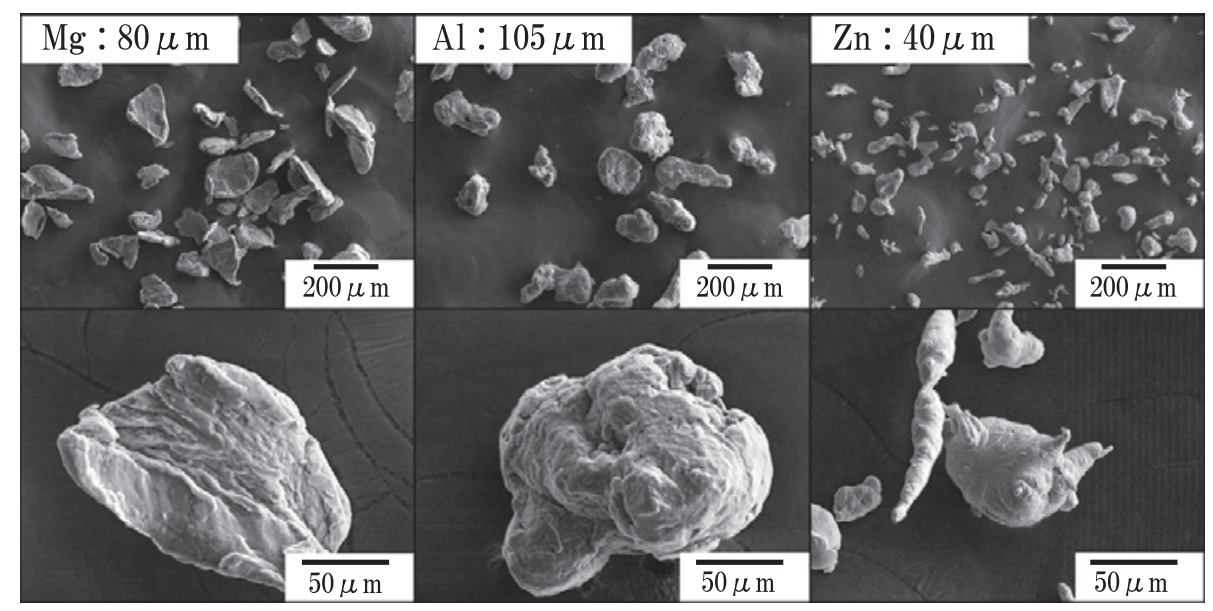

Fig.1 SEM images of mean particle size and shape of 3 types base powder.

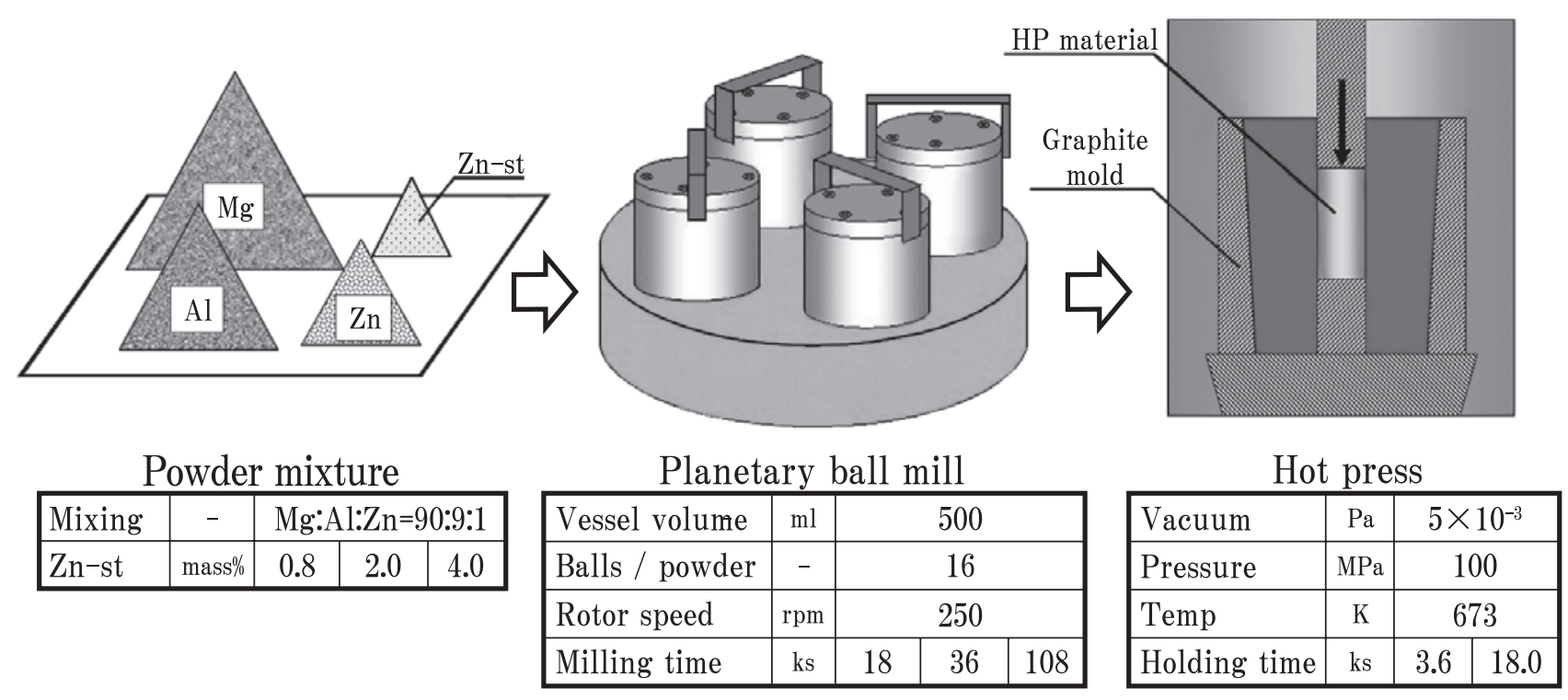

Fig.2 MA process and the condition.

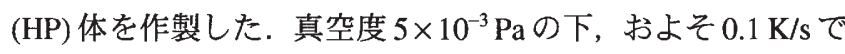
$673 \mathrm{~K}$ まで昇温した後, この温度で 3.6 おび $18.0 \mathrm{ks}$ 保持し， 同時に $100 \mathrm{MPa}$ の加圧をおこなった.

MA 粉末と HP 体の構成相の変化を調べるために, XRD お よびFE-EPMAを用いた. XRDは $\mathrm{CuK} \alpha$ 線を用いて回折速度 $33.3 \times 10^{-3} \mathrm{deg} / \mathrm{s}$ でおこなった. FE-EPMA は加速電圧 $15 \mathrm{kV}$, 照射電流 $3.88 \times 10^{-8} \mathrm{~A}$ で HP 体の面分析をおこなった。 また, 組織観察はFE-EPMAのSEMを用いた. 加速電圧は $15 \mathrm{kV}$, 照 射電流 $3.55 \times 10^{-9} \mathrm{~A}$ でおこなった. SEM 用試料は, 導電性樹 脂に埋め込んだ後, エメリ一紙 (\#400〜 800) で粗研磨しダイ ヤモンドペースト $(1 \sim 6 \mu \mathrm{m})$ およびマグネシアを用いてバフ 研磨により鏡面仕上げをおこなった. その後, ピクラル (ピ クリン酸 $4.2 \mathrm{~g}$, エタノール $70 \mathrm{ml}$, 酢酸 $10 \mathrm{ml}$, 蒸留水 $10 \mathrm{ml}$ ) を用いてエッチングをおこなった。

HP体の機械的性質を調べるために, ビッカース硬さ試験機
を用い, 10ケ所の硬さの平均値を求めた. 圧縮試験はオート グラフを用いた. 圧縮試験片は $\phi 6 \times 9 \mathrm{~mm}^{3}$ の円柱形に加工し, ひずみ速度がおよそ $0.002 / \mathrm{s} ゙$ 試験片が破壊されるまで圧縮を おこなった。

\section{3 実験結果及び考察}

3.1 MA 粉末

ミリング処理においてステアリン酸亜鉆を添加しなかった 場合, ミリング時間の增加に伴い粒子径は原料粉末と比較し て著しく增加し，108 ks で2〜3 mm となった. その粗大粒子 は $\mathrm{Al}$ 単相の層状組織を呈していた. さらに, 粉碎容器内の側 面やボールにも金属粗粉の象嵌に似た凝着がみられた ${ }^{8)}$. Fig.3はMA粉末の平均粒子径におよぼすステアリン酸要鈶の 添加量の影響を示す。ミリング時間の増加に伴い, その平均 粒子径の減少に対してステアリン酸亜鉛の添加効果が顕著に 


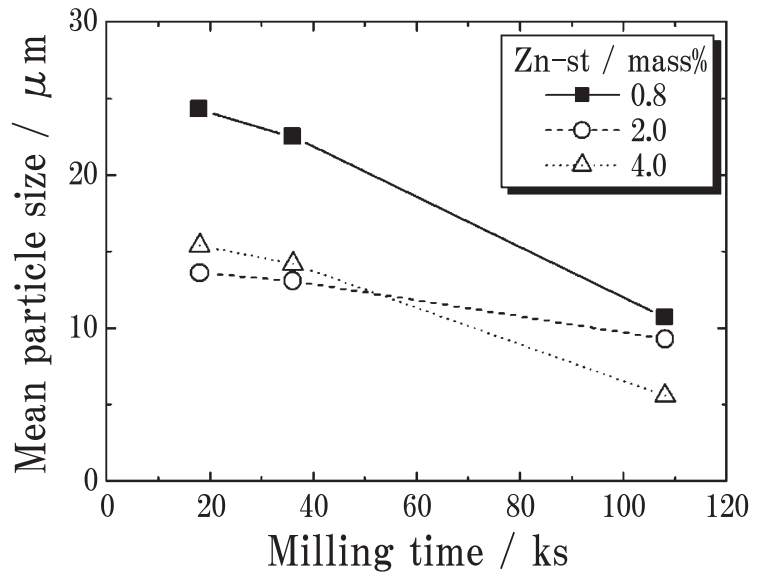

Fig.3 Effect by amount of zinc stearate.

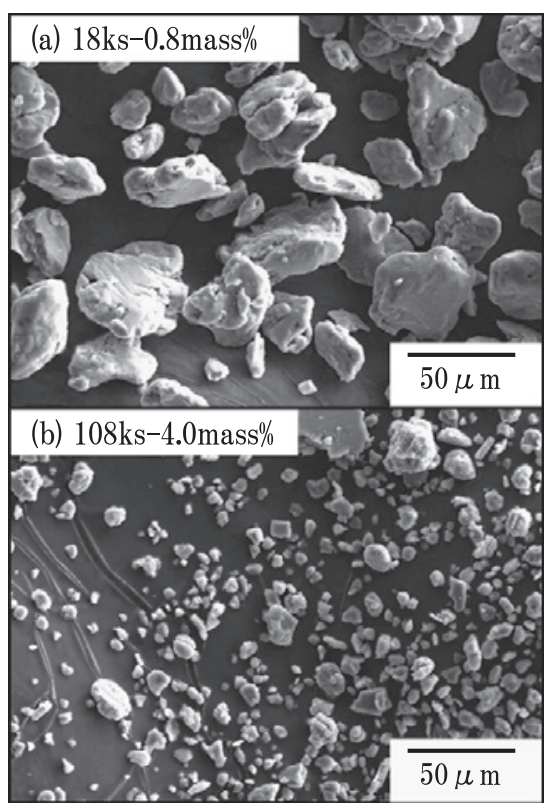

Fig.4 SEM images of MA powder produced through mechanical alloying for different milling times and amount of zinc stearate; (a) $18 \mathrm{ks}-0.8$ mass\%, (b) $108 \mathrm{ks}-4.0$ mass\%.

表れることがわかった. また, $108 \mathrm{ks}$ のリング処理により 平均粒子径が $5.6 \mu \mathrm{m}$ の MA粉末を得た. Fig.4はミリング時間 およびステアリン酸亜鉆の添加量によってミリング処理され たMA粉末のSEM像を示す. ステアリン酸亜鉛を添加するこ とによって粉末同士の凝着が抑制され, 加えて長時間のミリ ングによって粉研が促進されたと考えられる.

Fig.5 は様々な平均粒子径の MA 粉末の XRD 分析結果を示 す. 比較のためAZ91合金の回折パターン結果も載せてある. MA24. $3 \mu \mathrm{m}$ およびMA15. $4 \mu \mathrm{m}$ 粉末ではAl, Zn相の回折ピーク が見られそれぞれが残存していることを示唆している. $\mathrm{MA} 13.4 \mu \mathrm{m}$ 粉末では $\mathrm{Al}, \mathrm{Zn}$ 相の他に $\mathrm{Mg}_{17} \mathrm{Al}_{12}$ 相のブロードな 回折パターンの見られた.さらにMA10.7 $\mu \mathrm{m}$ おびMA5.6 $\mu \mathrm{m}$ 粉末においては $\mathrm{Al}, \mathrm{Zn}$ 相はほぼ消滅し $\mathrm{Mg}$ および $\mathrm{Mg}_{17} \mathrm{Al}_{12}$ 相 のみの回折ピークが確認された.MA 粉末の平均粒子径が小

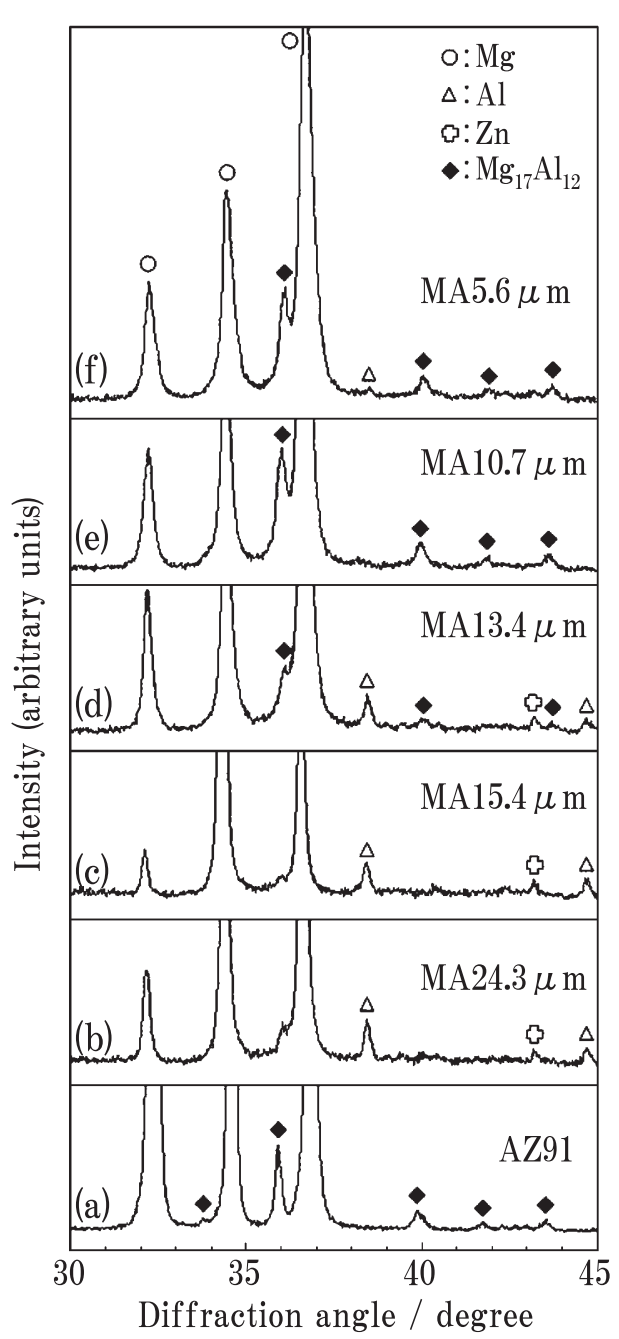

Fig.5 XRD patterns of MA powders with various mean particle sizes; (a) AZ91D, (b) MA24.3 $\mu \mathrm{m}$, (c) MA15.4 $\mu \mathrm{m}$, (d) MA13.4 $\mu \mathrm{m}$, (e) MA10.7 $\mu \mathrm{m}$, (f) MA5. $6 \mu \mathrm{m}$.

さくなりミリング処理が進行するに従い, $\mathrm{Mg}_{17} \mathrm{Al}_{12}$ 相の前駆 体として $\mathrm{Mg}$ 元素と $\mathrm{Al}$ 元素が相互に固溶し合う非晶質相が形 成されたと考えられる ${ }^{8}$.さらにミリング処理が進むと $\mathrm{Mg}$ 相 および平衡相の $\mathrm{Mg}_{17} \mathrm{Al}_{12}$ 金属間化合物のみが生成する.した がって, ミリング処理によって固相状態のまま合金化が起 こったと考えられる.

\section{$3.2 \mathrm{HP}$ 体の組織}

Fig.6 (a) は AZ91 合金の組織の SEM 像を示す．粒界に塊状 あるいはパーライト状の $\mathrm{Mg}_{17} \mathrm{Al}_{12}$ 相が観察された。 また，粒 界は部分的にジグザグ状であることから溶体化処理後に除冷 された一般的な $\mathrm{Mg}$ 合金の鋳造組織である ${ }^{p}$. Fig.6 (b), (c) お よび(d)はそれぞれ平均粒子径が24.3, 15.4および5.6 $\mu \mathrm{m} の \mathrm{MA}$ 粉末を $673 \mathrm{~K}$ で $3.6 \mathrm{ks}$ の真空焼結した HP 体組織の SEM 像を 示す.MA粉末別にそれぞれ異なった組織が観察された。こ れらの組織に生成した第 2 相の FE-EPMA による面分析結果 を Fig.7に示す. Fig.7 (a) は第 2 相の平均粒子径が $1 \sim 2 \mu \mathrm{m}$ 程 


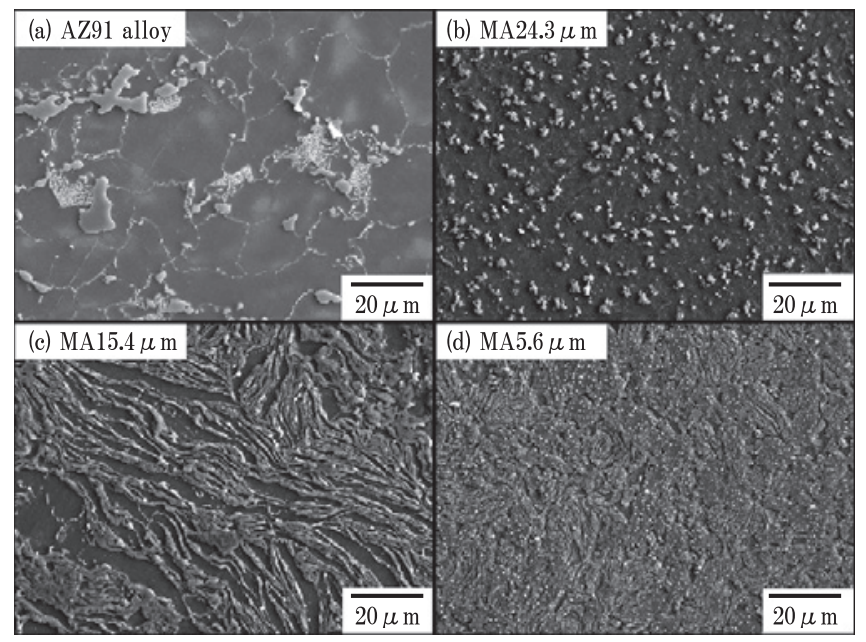

Fig.6 SEM images microstructure of sintered materials that hotpressed MA powder with various mean particle sizes at $673 \mathrm{~K}$ for $3.6 \mathrm{ks}$; (a) AZ91 alloy, (b) MA24.3 $\mu \mathrm{m}$, (c) MA $15.4 \mu \mathrm{m}$, (d) MA5.6 $\mu \mathrm{m}$.

度のMgを含む $\mathrm{Al}$ おびZnが濃化した相であることがわかつ た. Fig.7 (b)は糸状の第2相が無数に連なる縞模様が観察され た。この糸状の生成相はMA中に混入した酸素が残存し, $\mathrm{Mg}$ あるいはAl 酸化物になったと予想される. Fig.7 (c) は第 2 相 の平均粒子径がおよそ $0.2 \sim 0.3 \mu \mathrm{m}$ の非常に微細分散した $\mathrm{Mg}$ および $\mathrm{Al}$ の濃化，また部分的に糸状の $\mathrm{Mg}, \mathrm{Al}$ および $\mathrm{O}$ の濃 化が確認された。各 MA 粉末を焼結した HP体の XRD 分析結 果を Fig.8, Fig.9およびFig.10に示す．それぞれの図中の (a), (b) および (c) はそれぞれ保持時間が $0.0,3.6$ および $18.0 \mathrm{ks}$ に おけるHP体の回折パターンである.Fig.8の MA24.3 $\mu$ m 粉末 では，保持時間 (b) 3.6 および (c) $18.0 \mathrm{ks}$ において残存してい た $\mathrm{Al}, \mathrm{Zn}$ 相の回折ピークが消失し, 代わって $\mathrm{Mg}_{17} \mathrm{Al}_{12}$ 相の回 折ピークが見られた. Fig.9の MA15.4 $\mu \mathrm{m}$ 粉末では，保持時

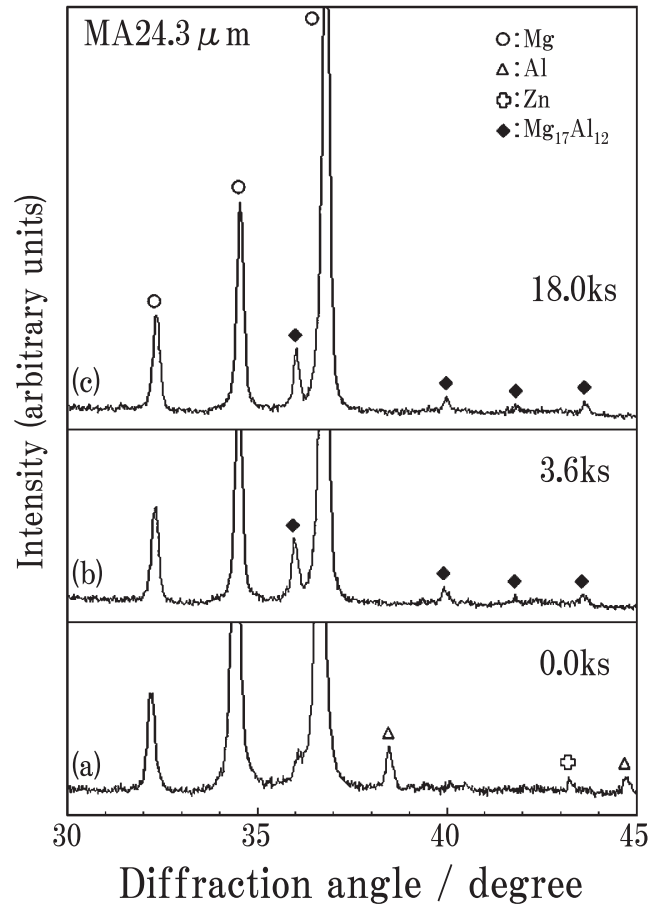

Fig. 8 XRD patterns of HP materials processed at $673 \mathrm{~K}$ for various holding time; (a) $0.0 \mathrm{ks}$, (b) $3.6 \mathrm{ks}$, (c) $18.0 \mathrm{ks}$ in MA24.3 $\mu \mathrm{m}$.

間の増加に伴い $\mathrm{Al}, \mathrm{Zn}$ 相の消失と $\mathrm{Mg}_{17} \mathrm{Al}_{12}$ 相の生成が起こつ た.さらに保持した場合ブロードな回折パターンが見られた. また, 前述で予想された酸化物相の回折ピークを確認すること はできなかった. Fig.10の MA5.6 $\mu \mathrm{m}$ 粉末においてはミリン グ処理の合金化によって生成した $\mathrm{Mg}_{17} \mathrm{Al}_{12}$ 相の回折ピークが, (b) 3.6 および (c) $18.0 \mathrm{ks}$ 保持した結果どちらもブロードな回 折パターンとなった.また, Fig.9の回折パターンと同様に酸 化物相の回折ピークは見られなかった.Fig.11に Mg-Al-Zn

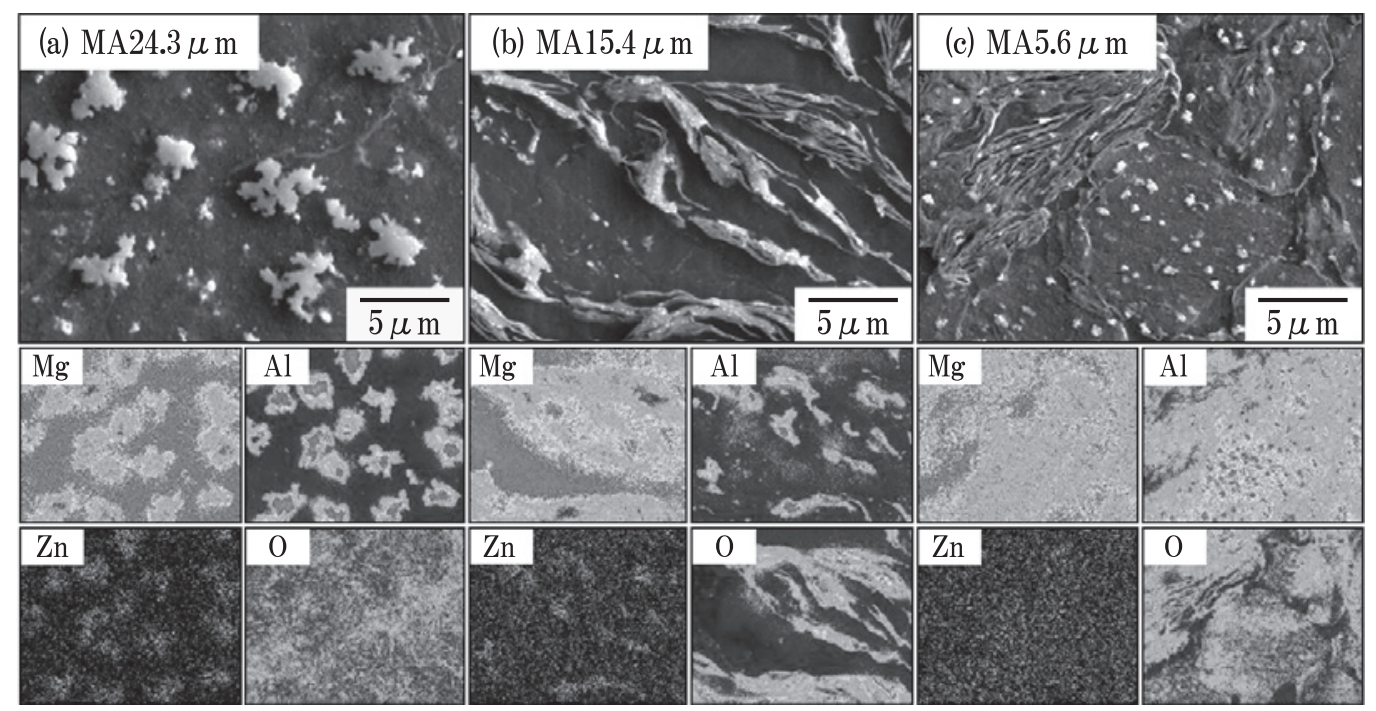

Fig.7 SEM images and corresponding map analysis of HP materials that processed MA powder with various mean particle sizes at $673 \mathrm{~K}$ for $3.6 \mathrm{ks}$; (a) MA24.3 $\mu \mathrm{m}$, (b) MA $15.4 \mu \mathrm{m}$, (c) MA5.6 $\mu \mathrm{m}$. 


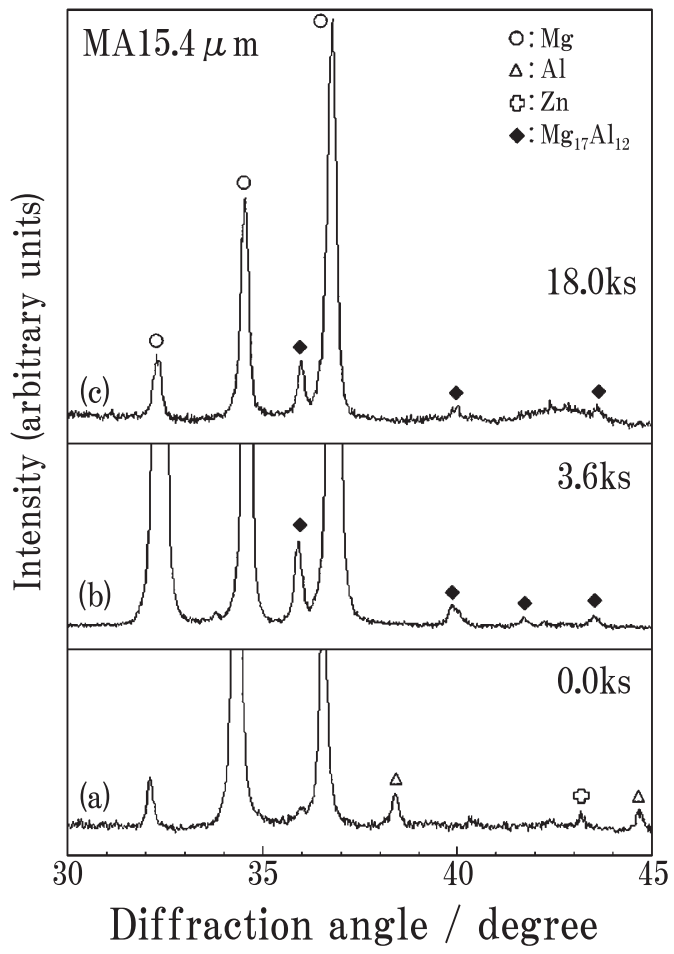

Fig.9 XRD patterns of HP materials processed at $673 \mathrm{~K}$ for various holding time; (a) $0.0 \mathrm{ks}$, (b) $3.6 \mathrm{ks}$, (c) $18.0 \mathrm{ks}$ in MA15.4 $\mu \mathrm{m}$.

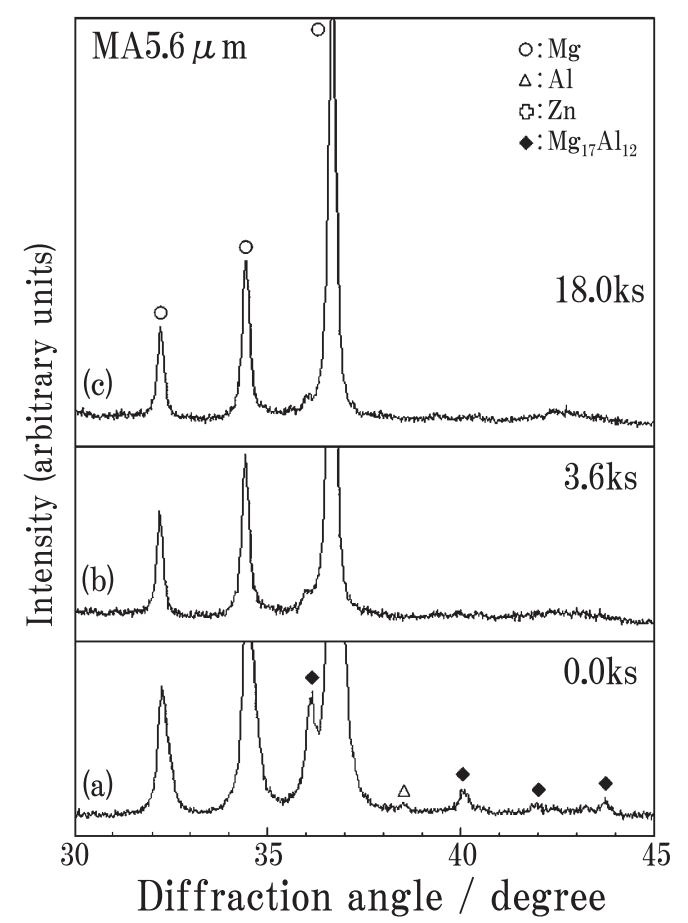

Fig.10 XRD patterns of HP materials processed at $673 \mathrm{~K}$ for various holding time; (a) $0.0 \mathrm{ks}$, (b) $3.6 \mathrm{ks}$, (c) $18.0 \mathrm{ks}$ in MA5.6 $\mu \mathrm{m}$.

系状態図 (溶解度面)を示す．室温における $\mathrm{Mg}$ マトリックス に対する AlおよびZnの最大固溶限はそれぞれ 4.0, 1.0 mass\% である。したがって，消失した $\mathrm{Zn}$ 相はほぼ全て $\mathrm{Mg}$ マトリッ

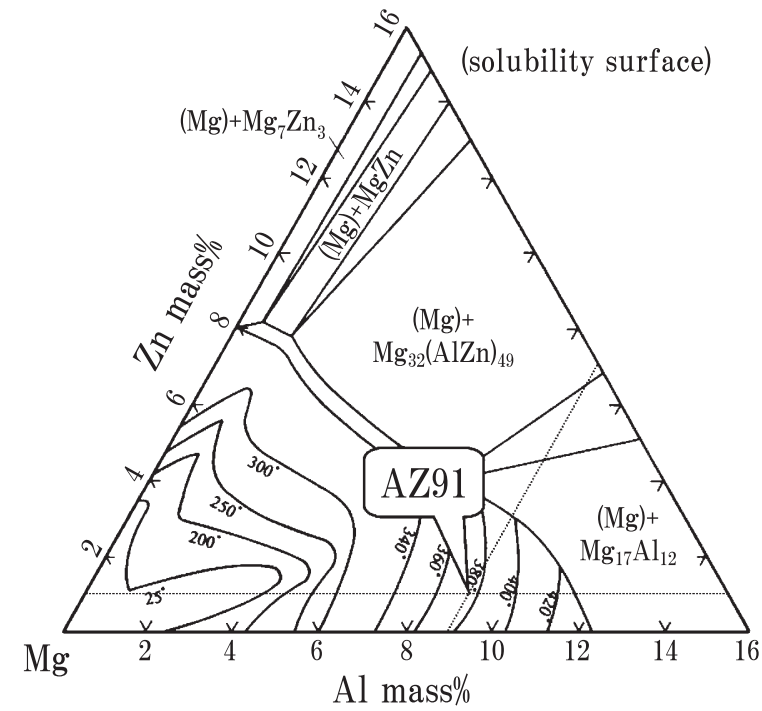

Fig.11 Mg-Al-Zn type phase diagram (solubility surface).

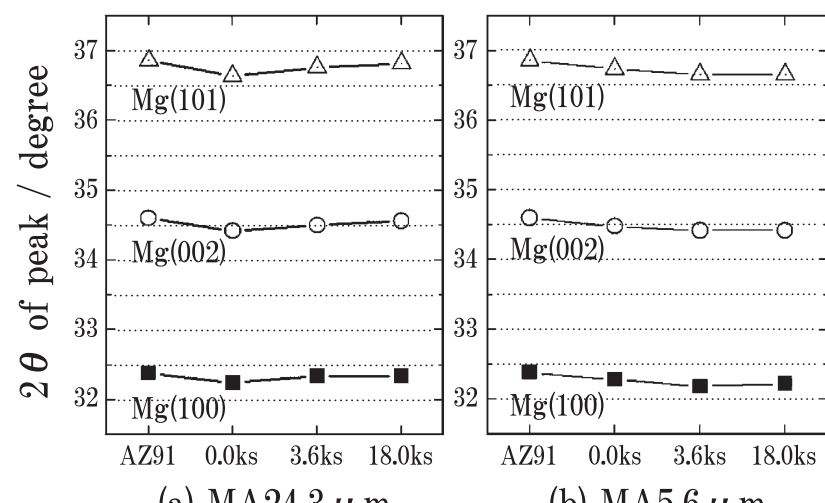

(a) MA24.3 $\mu \mathrm{m}$

(b) MA5.6 $\mu \mathrm{m}$

Fig.12 Change of $2 \theta$ of diffraction peak in HP materials; (a) MA24.3 $\mu \mathrm{m}$, (b) MA5.6 $\mu \mathrm{m}$.

クス中に固溶したと考えられる.一方, $\mathrm{Al}$ 相はホットプレス によって Mg マトリックス中に過飽和に固溶し非晶質相を形 成したため回折ピークがブロードなったと考えられる。 Fig.12はMg相の回折強度が大きい(100), (002)および(101)に おける回折ピークの $2 \theta$ の変化を示す. 比較のためにAZ91 合 金のそれも載せてある. 図中の(a), (b)はそそれぞれMA24.3 $\mu \mathrm{m}$, MA5.6 $\mu \mathrm{m}$ である. Fig.12 (a) では保持時間が増加するに従い $2 \theta$ の值はAZ91 合金のそれに近づくのに対し, Fig.12(b)では $2 \theta$ の值は低角側にシフトしている.このことは (a) ではミリ ング処理により一度膨張した結晶格子が保持時間の増加に 伴って回復し, (b)では非晶質相の生成により結晶格子が膨張 したと考えられる.

\section{$3.3 \mathrm{HP}$ 体の機械的性質}

Fig.13はMA粉末の平均粒子径および保持時間を変化させ たときのHP体の圧縮応力ー歪曲線を示す. 比較のためAZ91 合金の曲線も載せてある. MA2 $2.3 \mu \mathrm{m}$ 粉末の HP 体では延性 的挙動を示したのに対し, その平均粒子径が小さい HP 体で 


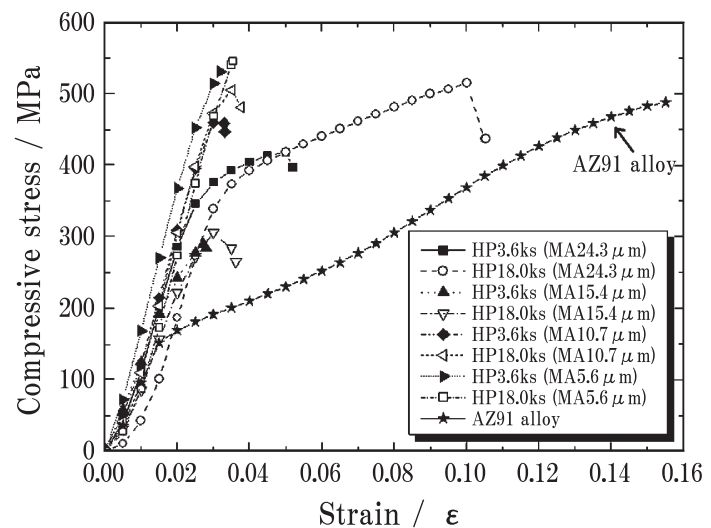

Fig.13 Compressive stress-strain curves of HP materials processed at $673 \mathrm{~K}$ for various conditions, and AZ91 alloy.

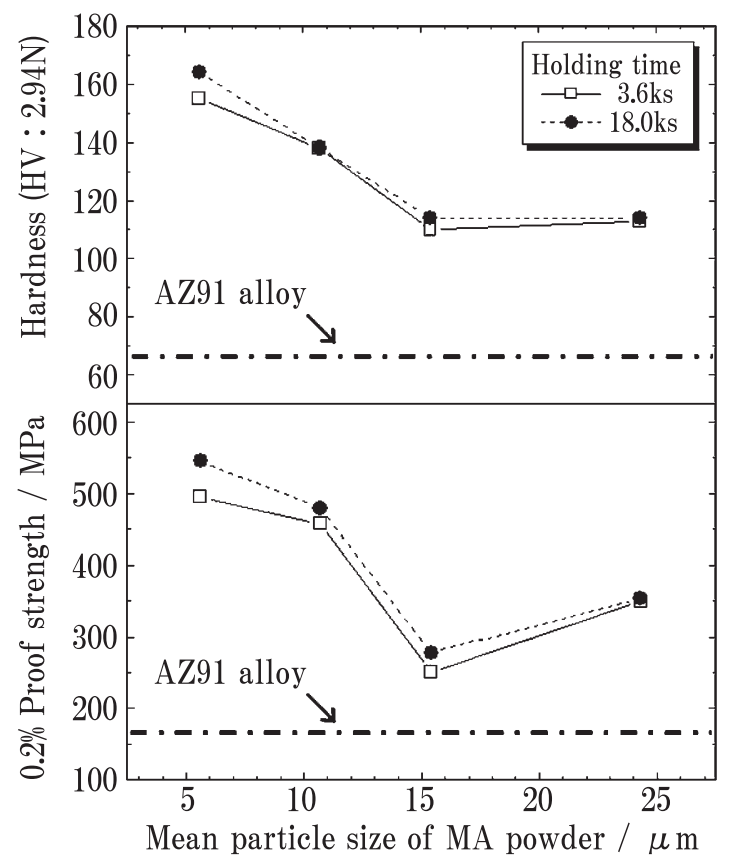

Fig.14 Relation between hardness, $0.2 \%$ proof strength and mean particle size of MA powder.

はセラミックス材料で見られるような脆性的挙動を示した. Fig.14はMA粉末の平均粒子径とビッカース硬さおよび0.2\% 耐力の関係を示す．比較のため AZ91 合金のそれぞれの值を 図中に示している.ビッカース硬さおよび0.2\%耐力は共に全 ての MA 粉末において AZ91 合金より優れた值を示し，その 平均粒子径が減少するに伴い増加している.これらの機械的 性質の変化は高いひずみを有する非晶質相が形成されたため $\mathrm{Mg}$ マトリックス中の転位密度が増大することにより起こっ

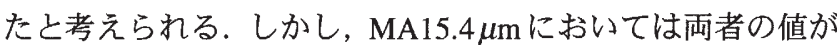
低下している. MA5.6 $\mu \mathrm{m}$ 粉末において保持時間の増加によ りビッカース硬さおよび $0.2 \%$ 耐力はそれぞれ HV 164, 546 MPaを示し本研究最大の値となった.このことはFig.10 (c)に おいて保持時間の増加に伴いFig.10(b)と比べてわずかに回折

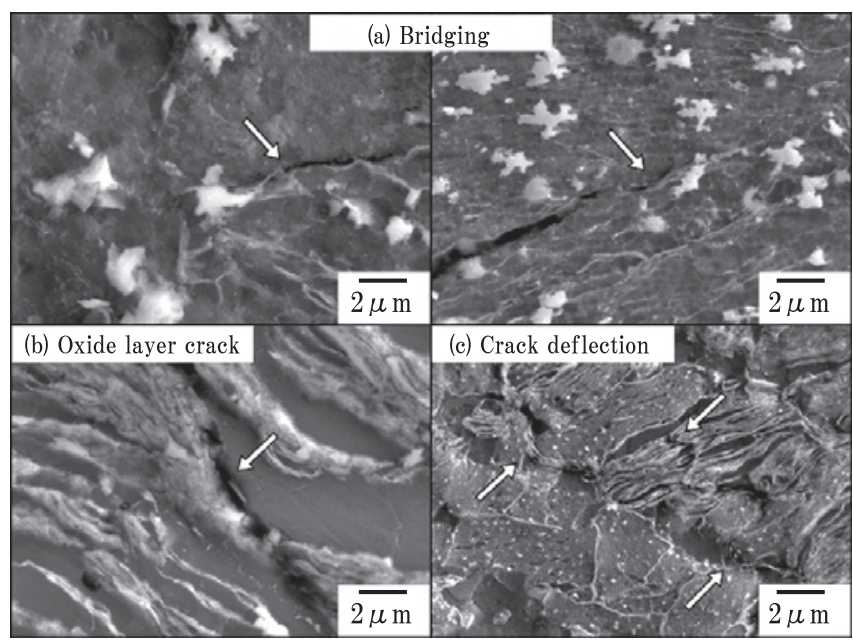

Fig.15 SEM images of various cracks; (a) bridging, (b) oxide layer crack, (c) crack deflection of HP materials processed MA powder with $24.3,15.4,5.6 \mu \mathrm{m}$ at $673 \mathrm{~K}$ for $3.6 \mathrm{ks}$.

ピークが見られることから，過飽和に固溶していた $\mathrm{Al}$ 相が ホットプレスの熱エネルギーによって非常に微細な $\mathrm{Mg}_{17} \mathrm{Al}_{12}$ 金属間化合物として $\mathrm{Mg}$ マトリックス中に分散し結晶格子を 膨張させたためと考えられる.

$3.4 \mathrm{HP}$ 体の破壊形態

Fig.15 は圧縮破壊後における HP 体の様々なクラックの SEM 像を示す. 図の (a), (b) および (c) は順にMA 粉末の平均 粒子径が24.3, 15.4および5.6 $\mu \mathrm{m}$ におけるHP体である. Fig. 15 (a) は第2相粒子によりクラックの進展が抑制されているのが 観察された. Fig.15 (b) は糸状の酸化物に沿って直線的にク ラックが進展しているのが見られた.この酸化物に沿ったク ラックによって早期に破壊が起こり硬さおよび $0.2 \%$ 耐力が低 下したと考えられる. Fig.15(c)においては微細に分散した第 2 相粒子の集団を避けるようにクラックが進行方向を変えな がら進展しているのが観察された. 特に (a), (c)においてはそ のクラックの形態はそれぞれBridging (架橋), Crack deflection (亀裂の偏向) と呼ばれる機構に類似している.これらの機構 はセラミックスの勒性向上の機構として提唱されている ${ }^{10)}$. したがって, MA $24.3 \mu \mathrm{m}$ 粉末における HP 体が延性的挙動を 示した理由として第2相粒子によるクラック進展の遅延効果 が考えられる。

\section{4 まとめ}

AZ91合金相当の粗粉にMA法を適用することによってMA 粉末から HP体を作製した.このHP体の組織および機械的性 質の変化を調べた結果, 以下のことがわかった.

(1) MA粉末の平均粒子径は, ミリング時間の増加に伴い小さ くなり長時間のミリングほどステアリン酸亜鉆の添加効 果が大きい. 特に, ミリング時間 $108 \mathrm{ks}$ ，ステアリン酸亜 鈆 $4.0 \mathrm{mass} \%$ のとき平均粒子径は $5.6 \mu \mathrm{m}$ となった.

(2) HP体の第2 相粒子は, FE-EPMA およびXRD 分析の結果 から $\mathrm{Mg}_{17} \mathrm{Al}_{12}$ 金属間化合物であることがわかった．また， 
MA15.4 $\mu \mathrm{m}$ 粉末におけるHP体には糸状の酸化相が確認さ れた。これは大気中および原料粉末から混入したためと 考えられる.

(3) HP 体の第 2 相粒子は, MA 粉末の平均粒子径が小さくな るに従い平衡相である $\mathrm{Mg}_{17} \mathrm{Al}_{12}$ から非晶質相へと変化し 硬さおよび $0.2 \%$ 耐力が増加したと考えられる.

(4) HP 体の硬さおよび $0.2 \%$ 耐力は保持時間の増加に伴いそ れぞれ本研究最大の HV164, $546 \mathrm{MPa}$ を示した. これは微 細分散した $\mathrm{Mg}_{17} \mathrm{Al}_{12}$ 金属間化合物によるものと考えられ る。

(5) MA24.3 $\mu \mathrm{m}$ におけるHP体は圧縮試験において延性的挙動 を示した.これは第2相粒子による架橋効果あるいは保持 時間の増加による加工硬化の回復が起こったと考えられ る.

\section{文献}

1) Y.Kojima, S.Kamado, K.Higashi and T.Aizawa: "Platform Science and Technology for Advanced Magnesium Alloys", Journal of Japan Institute of Light Metals, 51(2001)575-585.

2) S.Kamado and Y.Kojima: "Development of Heat-resistant Magnesium Alloys for Automotive Engine Parts", Bulletin of the Iron and Steel Institute of Japan, 11(2006)131-136.

3) M.Sugamata: "Handbook of Advanced Magnesium
Technology", Kallos Publishing Co., Ltd, (2000)276-280.

4) A.Yamazaki, J.Kaneko and M.Sugamata: "Solid State Reaction in Mechanical Alloyed Materials of the $\mathrm{Mg}-\mathrm{SiO}_{2}$ System", J. Jpn. Soc. Powder Powder Metallurgy, 48(2001)61-66.

5) A.Yamazaki, J.Kaneko and M.Sugamata: "Solid State Reaction in Mechanical Alloyed Magnesium with Addition of LowMelting-Metal Oxides", J. Jpn. Soc. Powder Powder Metallurgy, 48(2001)397-403.

6) A.Yamazaki, J.Kaneko and M.Sugamata: "Solid State Reaction in Mechanical Alloying of the Mg-9\%Al Alloy with Addition of $\mathrm{TiO}_{2}$ and $\mathrm{ZrO}_{2}{ }^{\prime \prime}$, J. Jpn. Soc. Powder Powder Metallurgy, 48 (2001)935-942.

7) A.Yamazaki, J.Kaneko and M.Sugamata: "Mechanical Alloying of Magnesium and $\mathrm{Mg}-\mathrm{Al}$ Alloys with $\mathrm{MnO}_{2}$ and $\mathrm{Fe}_{2} \mathrm{O}_{3}{ }^{\prime \prime}$, Journal of Japan Institute of Light Metals, 52(2002)421-425.

8) H.Oginuma, A.Ohguchi, S.Ohno, E.Yuasa and Y.Oki: "Crystal Phase Formed in Mechanical Alloying of $\mathrm{Mg}-\mathrm{Al}-\mathrm{Zn}$ Powder Mixtures Using Magnesium Alloy Machined Chips", J. Jpn. Soc. Powder Powder Metallurgy, 52(2005)416-422.

9) E.Sato: "Handbook of Advanced Magnesium Technology", Kallos Publishing Co., Ltd, (2000)73-74.

10) T.Sakuma: "Ceramic Zairyougaku", Kaibundoushuppan, (1990) 189-191. 